Review Article

\title{
QUALITY PARAMETERS OF BULGARIAN KINDS OF BEE HONEY
}

\author{
Dinko Hristov Dinkov \\ Department of Hygiene and Technology of Animal Foodstuffs, \\ Veterinary Legislation and Management, \\ Faculty of Veterinary Medicine, Trakia University, \\ 6014 Stara Zagora, Bulgaria
}

Received 11 October 2013; Received in revised form 16 December 2013; Accepted 8 January 2014

\begin{abstract}
More than 3600 varieties of higher plants are found in Bulgaria, which is a good predisposition for the production of different types of bee honey. In the country 11 natural and 3 national parks were registered, where many different kinds of plants can be found, some of them unique in the world. Up till now, more than 11 types of bee honey have been harvested and investigated. The aim of this work was, based on the data from available literature to provide a summary of the scientific information related to the main types of bee honey in Bulgaria from 2000 to the present. In the study, we present quality parameters from organically produced and commercially processed bee honeys: pollen analysis, proline content, invertase activity, specific optical rotation, electrical conductivity, antioxidant and antibacterial activities.
\end{abstract}

Key words: types of honey, quality, Bulgaria

The Bulgarian dendroflora consists of 359 species, including 368 infraspecific taxa (60 subspecies, 200 varieties and 108 forms) $(28,39)$. There are about 770 species of medicinal plants constituting $20 \%$ of the Bulgarian flora. Of these, 200 are currently in use and over 250 herbal drugs are derived from them and presently used in the prophylaxis and medicine, cosmetics and the food industry (24). Bulgarian medicinal plants have a broad diversity of species, rich composition of active ingredients and most of them are nectariferous with great importance for bees.

The aim of this work was, based on the data from available literature to provide a summary of the scientific information related to the main types of bee honey in Bulgaria in the first decade of the $21^{\text {st }}$ century

Corresponding author: Assoc.Prof. Dinko Hristov Dinkov, PhD E-mail address: dinkodinkov@yahoo.com

Present address: Department of Hygiene and Technology of Animal

Foodstuffs, Veterinary Legislation and Management

Faculty of Veterinary Medicine, Trakia University

6014 Stara Zagora, Bulgaria

tel. +35942699539/mobile +359889985416

Copyright: (C) 2014 Dinkov D. This is an open-access article published under the terms of the Creative Commons Attribution License which permits unrestricted use, distribution, and reproduction in any medium, provided the original author and source are credited.

Competing Interests: The authors have declared that no competing interests exist.

Available Online First: 13 January 2014

http://dx.doi.org/10.14432/j.macvetrev.2014.01.007

\section{Pollen analysis}

In 2001, the type of the 130 investigated batches unprocessed bee honey was from honeybees determined via pollen analysis. It was found out that $47.69 \%$ of the batches were multifloral and $52.31 \%$ - monofloral honeys. In $56.45 \%$ of multifloral honeys, the sunflower pollen ranged between 20 and $40 \%$. Among monofloral varieties, the most prevalent was sunflower honey (44.12\%) followed by acacia and lime honeys $(20.58 \%$ each), clover honey $(8.82 \%)$ and alfalfa honey $(5.88 \%),(19)$.

In 2006, from, 11 honey samples harvested from the villages from the Shumen region, four types of unifloral honey were indentified (Helianthus annuus, Robinia pseudoacacia, Paliurus and Apiaceae), (29).

In recent years, consumers worldwide show great interest in unifloral bee honeys, preferably collected from one type of plants, with high quality and specific sensorial characteristics. What is especially of interest now, related to this, is the issue of the description of unifloral bee honeys, harvested in differents countries.

The available data showed that the most common unifloral honey types in different regions of Bulgaria during 2006-2009 were black locust, lime, sunflower, and rape honeys. The ranking of average pollen concentrations for the honeys studied was Brassica $>$ Helianthus $>$ Tilia $>$ Robinia (3). 
Based on the last available analyses of Bulgarian types of honey, the most important are acacia honey, sunflower honey, coriander honey, multifloral honey and honeydew honey (4). This conclusion could be supplemented with scientific data for other Bulgarian's types of honey.

In the last decade of the $21^{\text {st }}$ century in Bulgaria, extensive researche has been conducted for some rare types harvested in the country and types of unifloral honey for which there is a lack of knowledge.

\subsection{Coriander honey}

In Bulgaria, Coriandrum sativum L., is a very good nectariferous plant important for the bees, predominantly planted in South Bulgaria.

In 2009, there was a study of the main quality parameters (6), of Bulgarian's coriander (Coriandrum sativum L.), honey $(n=10)$, harvested near the village of Daskal Atanasovo, region of Stara Zagora, Bulgaria. For the first time there was recording of data for $\mathrm{pH}(4.71 \pm 0.03)$, free acidity $\left(35 \pm 0.5 \mathrm{meq} \cdot \mathrm{kg}^{-1}\right)$, invertase activity $(15.9 \pm 0.04 \mathrm{IN})$, electrical conductivity $\left(0.3564 \pm 0,0004 \mathrm{mS} . \mathrm{cm}^{-1}\right)$ and specific optical rotation - (-) $14.5 \pm 0.1$ $[\alpha]_{\mathrm{D}}{ }^{20}(21 ; 22)$. The high values of free acidity $\left(35 \pm 0,5\right.$ meq. $\left.\mathrm{kg}^{-1}\right)$ and $\mathrm{pH}(4,71 \pm 0,03)$, in our samples, could be related to 3,4-dimethoxybenzoic acid, 3,4-dimethoxybenzene acetic acid, 2,3-dimethoxybenzaldehyde and vanillyl alcohol found in this type of honey (25).

\subsection{Fennel honey}

In Bulgaria, fennel is cultivated in many areas preferably in the northern parts of the country, in the regions of Varna, Ruse, Shumen etc.

In the essential oils from fennel (Foeniculum vulgate Mill.) different components were found: trans-Anethole (31-36\%), alpha-pinene (14-20\%) and limonene (11-13\%) were the main components of the essentials oil isolated from dried aerial parts, whereas methyl chavicol (= estragole) (79-88\%) was dominant in the fruit oils (30).

Recent scientific studies have indicated the usefullness of Foeniculum vulgate Mill., extracts in medicine. Specific antibacterial activities have been detected for such microorganisms as Candida albicans (35), Helicobacter pylori and Campylobacter jejuni (8).

In available references only one study was found concerning the for usefulness for medicinal purposes of fennel bee honey (Foeniculum vulgate Mill.), with origin from Egypt (45). Despite of the lack of description of the quality characteristics of bee honey used in the experiments, this honey was described as fennel and was used to evaluate the potency of rats treated with this type of honey to overcome an induced infection with the microorganism Staphylococcus aureus .

In Europe complex investigations have been carried out about the quality characteristic of most unifloral bee honeys (34). In the available references, there was no description of fennel bee honey (Foeniculum vulgare Mill.). Only Spanish studies have found foeniculum vulgare-type pollen in all the samples of multifloral honeys from different apiaries in La Palma (Canary Islands) (42, 43) and El Hierro (Canary Islands), (41).

In 2011, the main quality parameters of Bulgarian fennel (Foeniculum vulgare Mill.), bee honey, harvested in 2009 near the village of Ostrovo in the region of Razgrad, Bulgaria, were presented (36). For the first time there was recorded data for $\mathrm{pH}$ $(4.76 \pm 0.06)$, free acidity $\left(25.30 \pm 1.33 \mathrm{meq} \cdot \mathrm{kg}^{-1}\right)$, diastase activity $(22.7 \pm 0.1 \mathrm{DN})$, invertase activity $(29.85 \pm 0.43 \mathrm{IN})$, electrical conductivity $\left(0.4612 \pm 0.019 \mathrm{mS} . \mathrm{cm}^{-1}\right), \quad$ specific optical rotation (-) $14.8 \pm 0.25[\alpha]_{\mathrm{D}}{ }^{20}$ and proline content $\left(230.65 \pm 0.35 \mathrm{mg} \cdot \mathrm{kg}^{-1}\right)$. Quantity of fructose $(44.9 \pm 0.2 \mathrm{~g} / 100 \mathrm{~g})$, glucose $(25.5 \pm 0.3 \mathrm{~g} / 100 \mathrm{~g})$, sum of glucose and fructose $(70.4 \pm 0.3 \mathrm{~g} / 100 \mathrm{~g})$, and low level of apparent sucrose $(<\mathrm{LOQ})$, indicated that fennel bee honey belongs to blossom honeys. Maltose, melibioze and melizitose were not detected in fennel honey. Other investigated sugars were in low quantity in this new type of honey (turanose $1.34 \pm 0.23$; treahalose $-0.29 \pm 0.04 \mathrm{~g} / 100 \mathrm{~g}),(36)$.

Our results for fructose $(44,9 \pm 0,2 \mathrm{~g} / 100 \mathrm{~g})$, glucose $(25,5 \pm 0,3 \mathrm{~g} / 100 \mathrm{~g})$, sum of glucose and fructose $(70,4 \pm 0,3 \mathrm{~g} / 100 \mathrm{~g})$, and low level of apparent sucrose $(<\mathrm{LOQ})$ in fennel honey (36), indicated that this type belongs to blossom honeys according to the requirements of the European Honey Commission (6) and the European Council Directive 2001/110/EC (23).

\section{Proline content}

The application of the method of the European Honey Commission (6) in Bulgaria for determination of proline content in honey from honeybees was discussed for the first time in 2000. Data concerning the proline content in nonprocessed multifloral and honeydew honeys from different producers is presented. A higher minimum value of proline content in multifloral honeys $\left(267.0 \pm 23.71 \mathrm{mg} . \mathrm{kg}^{-1}\right)$ was detected, in comparison to DIB norms (9). The differences between the results for multifloral and honeydew types of honey were statistically significant. It was suggested that proline content could be a useful additional criterion for identification of honeydew honeys with higher 
value of proline content, in comparison to the multifloral types of honey (10).

\section{Invertase activity}

Furthermore, in 2000 invertase activity was determined for 10 multifloral and 10 honeydew honeys from different regions in Bulgaria in accordance with the Harmonized Methods of the European Honey Commission (6). The aim of the study was to determine the variability of invertase activity for multifloral and honeydew honeys and to establish the characteristic range of the enzyme and the sensitivity to heating for multifloral honeys. The results showed that invertase activity varied considerably in multifloral $(6.06 \pm 5.92)$ honeys. The invertase activity of multifloral and honeydew honeys was different and statistically significant $(p<0.001)$. It was found that invertase in multifloral honey was statistically $(p<0,001)$ sensitive to the heating usually applied in some Bulgarian factories (18).

According to the Harmonized Methods of the European Honey Commission (6), the invertase activity in four types of Bulgarian bee honeys harvested in 2007 (sunflower, clover, multifloral and mixed honeydew and multifloral), from two regions - southern Bulgaria (Haskovo region) and northern Bulgaria (Montana region), was investigated. Investigated bee honey types from southern Bulgaria showed significantly different $(\mathrm{p}<0.01)$, high values for invertase activity $(35.75 \pm 0.21 \mathrm{IN} ; 24.577 \pm$ $0.109 \mathrm{IN}$ and $23.762 \pm 0.13 \mathrm{IN})$, in comparison to honeys from northern Bulgaria (11.431 $\pm 0.36 \mathrm{IN}$ and $10.066 \pm 0.46 \mathrm{IN})$. The highest values of invertase activity were found in multifloral bee honey harvested near the town of Madzharovo $(35.75 \pm 0.21 \mathrm{IN})$, and the lowest values $(10.066 \pm 0.46 \mathrm{IN})$, from sunflower bee honey from the village of Erden, the Montana region (20).

There was, also, an investigation in Bulgaria of the influence on invertase activity from low processing temperatures $\left(37^{\circ} \mathrm{C}\right.$ и $\left.42^{\circ} \mathrm{C}\right)$, in four types of Bulgarian bee honeys (sunflower, clover, multifloral and mixed honeydew and multifloral), from two regions - southern Bulgaria (Haskovo region) and northern Bulgaria (Montana region), in accordance with the method, recommended by the European Honey Commission (6). The temperature treatment with $37^{\circ} \mathrm{C}$ for less than $24 \mathrm{~h}$ leads to the increasing of invertase activity from investigated types of bee honey. In $80 \%$ in the all cases was found statistically significant reduction $(\mathrm{p}<0.01)$ of invertase activity under $42^{\circ} \mathrm{C}$, in comparison to $37^{\circ} \mathrm{C}(16)$.

\section{Specific optical rotation}

For the first time in Bulgaria the specific optical rotation $[\alpha]_{\mathrm{D}}{ }^{20}$ was determined in 29 honeys (Robinia sp. $\mathrm{n}=10$, multifloral $\mathrm{n}=10$, honeydew $\mathrm{n}=9$ ), (11), produced in 2000, from various regions and different phytogeographical areas according to the Harmonized Methods of the European Honey Commission (6). It was estimated that the specific optical rotation of the Robinia honeys was (-) $17.0 \pm 1.2$, which was similar to previously reported values $(33,40)$. The average value of the multifloral honeys was (-) $14.8 \pm 4.9$, which was similar to the values of multifloral honeys found by Sacchi \& Bosi (44), and to those found in Robinia honeys. The values of the specific optical rotation of Bulgarian honeydew honeys were positive $(4.2 \pm 1.3)$, which is consistent with other results $(5,26,27,32,44)$. However these values were lower than those found in Italian honeydew honeys, which varied from 13.6 to 16.6 .

Our data of the specific optical rotation of the Bulgarian coriander honey - (-) 14,5 $\pm 0.1[\alpha]_{D}{ }^{20}(20$, 21 ), showed approximate values to those previously reported for multifloral - (-) $14.8 \pm 4.9[\alpha]_{\mathrm{D}}{ }^{20}$ and Robinia spp. - (-) $17.0 \pm 1.2[\alpha]_{\mathrm{D}}{ }^{20}$, honeys (10).

\section{Electrical conductivity}

In 2007 there was a research of the conductivity of multifloral and honeydew honeys from different regions in Bulgaria. It presented data derived from 142 samples multifloral and honeydew honeys from two periods: 2000-2004 and 2005-2006. In the first period the mean values of electrical conductivity of multifloral honeys was determined to be 0,6221 $\mathrm{mS} . \mathrm{cm}^{-1}$ and for honeydew honeys $-0,8686 \mathrm{mS} . \mathrm{cm}^{-1}$. The highest mean values of conductivity were found in samples produced in August 2006 from the town of Madzarovo (Bulgaria) $-0.9414 \mathrm{mS} . \mathrm{cm}^{-1}$. Aspecial attention was paid to electrical conductivity as a contemporary method for bee honey quality assessment (13).

\section{Complex physical and chemical parameters}

In 1999 the principal physical and chemical parameters of 130 batches of bee honey originating from 9 regions of the country were analyzed. Deviations in the water content $(16.16 \%)$, total acidity (14.62\%), content of reducing sugars (1.54\%), saccharose content $(2.31 \%)$ and diastase activity $(10.77 \%)$ were observed. They were the most commonly encountered in sunflower honey (33.33\% with changed water content and total acidity of $6.67 \%$ with variations in the content of 
reducing sugars, saccharose and diastase activity). The acacia honey had the lowest water content, total acidity and diastase activity. The linden honey showed decreased diastase activity in $35.72 \%$ of all cases. The multifloral honey had the lowest content of reducing sugars and hydroxymethylfurfurol, although in $12.92 \%$ of the samples its water content was increased; $14.52 \%$ had increased total acidity and $6.46 \%$ - had decreased diastase activity (17).

In 2005 , a review of the physical and chemical criteria and standards in bee honey analysis in Bulgaria was conducted (12). Along with the widely used parameters such as water content, content of sugars etc., a special attention was paid to proline content, invertase activity and specific optical rotation as contemporary methods for bee honey quality assessment. The Bulgarian values for certain types of bee honey, that are also encountered in other Balkan countries are provided: invertase activities of honeydew and multifloral honey - 30.48 IN and 11.0 IN respectively; acacia honey - 3.8 IN; proline content ( $>180 \mathrm{mg} \cdot \mathrm{kg}^{-1}$ in honeydew honey), multifloral honey $\left(267.2 \mathrm{mg} \cdot \mathrm{kg}^{-1}\right)$, tilia honey (469 mg. $\mathrm{kg}^{-1}$ ), acacia honey (213.4 mg. $\mathrm{kg}^{-1}$ ) and specific optical rotation: (-) 17 and (-) $15.1[\alpha]_{\mathrm{D}}{ }^{20}$ in acacia honey and $4.9[\alpha]_{\mathrm{D}}{ }^{20}$ honeydew honey (12).

\section{The antioxidant and antibacterial activities}

At the " 1 st World Honeydew Honey Symposium", Apimondia International Honey Commission, 1 to $3^{\text {rd }}$ of August 2008 in Tzarevo, Bulgaria, there was a presentation of the antioxidant activities of multifloral, acacia and honeydew honeys. The percentages of antioxidant activities ( $\%$ AA) of different honeys were assayed in vitro using the method of Al-Mamary et al. (1). The percentage of AA was measured in diluted honey samples by calculating the inhibition of pig liver homogenate oxidation mediated by the $\mathrm{FeSO}_{4}$ ascorbate system. The antioxidant activity of different honeys increased with the increase of the levels of honey samples solutions $(50 \mu \mathrm{l}, 100 \mu \mathrm{l}$ and $200 \mu \mathrm{l})$. In all cases the highest values of antioxidant activity were found in honeydew honeys. The honeydew honeys harvested near the town of Madzharovo had the highest antioxidant activity $-9.91 \%$ with $50 \mu \mathrm{l}$, $35.64 \%$ with $100 \mu \mathrm{l}$, up to nearly two times higher $(63.33 \%)$ with $200 \mu \mathrm{l}$ from sample solution (14).

In 2009 the first clinical case of detected specific antibacterial activity from oak honeydew honey isolated from wound pathogen strain Staphylococcus aureus resistant to amoxicillin, kanamycin, lincomycin, erythromycin, doxycyclin and chloramphenicol was presented (15).

\section{Production of organic honeys}

Bee honey produced in organic apiculture conditions should be natural, without contaminants $(7,46)$.

Organic beekeeping is beekeeping practiced in clean areas, without intensive agriculture. For 2005, 23508 certified beehives produced 984 tons of organic bee products, most of it being honey. At the end of 2009, there were about 35000 certified apiaries working according to the 834/2007 EC Directive, producing 1,680 tons of organic honey per year. The number of certified beekeepers is not precisely known, as some of them are certified as a group, but it is estimated to be between 100 and 150 . Analyzing the data from the last available census from 2003, the total agricultural area in the country was $29045 \mathrm{~km}^{2}$. If we adopt that total area of Bulgaria is $108489 \mathrm{~km}^{2}$, we can see that workable agricultural areas amount to $26.7 \%$ (29 $044.8 \mathrm{~km}^{2}$ ), and the rest $73.3 \%$ (79 $444.2 \mathrm{~km}^{2}$ ), must belong to uncultivated areas. We could generalize that, these uncultivated areas are good sites for organic beekeeping, on the condition that there are no contaminating industries. Thus organic beekeeping in Bulgaria has very good conditions from a territorial point of view (2).

The invertase activity and carbohydrate spectrum of organic acacia and multifloral honeys produced in the South Stara Planina region (Republic of Bulgaria) were investigated. After one year of storage at a temperature up to $25^{\circ} \mathrm{C}$, a mild reduction in invertase activity (3.9-4.79\%) has occurred in multifloral honey. The activity of this enzyme decreased considerably in acacia honey (15.16\%). The average content of carbohydrates of acacia honey after one-year storage was: fructose $-42.76 \pm 1.24 \mathrm{~g} / 100 \mathrm{~g}$, glucose $-27.5 \pm 1.11 \mathrm{~g} / 100 \mathrm{~g}$, fructose/glucose ratio $-1.55 \pm 0.05$, sucrose $-0.60 \pm 0.63 \mathrm{~g} / 100 \mathrm{~g}$, turanose $-1.18 \pm 0.21 \mathrm{~g} / 100 \mathrm{~g}$, maltose $-0.54 \pm 0.36 \mathrm{~g} / 100 \mathrm{~g}$, trehalose $-0.28 \pm 0.04 \mathrm{~g}$ $/ 100$ g.The respective carbohydrates in multifloral honey were fructose $(41.16 \pm 0.81 \mathrm{~g} / 100 \mathrm{~g})$, glucose $(27.11 \pm 0.85 \mathrm{~g} / 100 \mathrm{~g})$, fructose/glucose ratio $(1.51 \pm 0.07)$, sucrose $(0.14 \pm 0.20 \mathrm{~g} / 100 \mathrm{~g})$, turanose $(1.17 \pm 0.26 \mathrm{~g} / 100 \mathrm{~g})$, maltose $(0.90 \pm 0.69 \mathrm{~g} / 100 \mathrm{~g})$, and trehalose $(0.65 \pm 0.19 \mathrm{~g} / 100 \mathrm{~g})$. Neither melibiose nor melezitose were established in both types of honey (38).

The information about the circumstances influencing the quality of organically produced honey, allowed us in 2012 to recommend more specific conditions of processing, storage and utilization of this unique foodstuff in order to 
preserve its natural organoleptic, physical, chemical and antibacterial features:

- During processing, heating $>37{ }^{\circ} \mathrm{C}$ should be prohibited, and the second processing after harvesting should be done via heating $<37^{\circ} \mathrm{C}$;

- Storage conditions should be at temperatures $<20{ }^{\circ} \mathrm{C}$ (the optimum temperature is $10-16^{\circ} \mathrm{C}$ ) and relative humidity $<65 \%$;

- Shelf life (best before...) should not exceed: 2 years after packaging (for unheated, industrially unprocessed and filtered organic honey) and 1 year after packaging (for industrially unprocessed and filtered organic honey heated only at temperatures $<37^{\circ} \mathrm{C}$ ), (37).

We agree with other scientists that unifloral commercially produced or organic honeys are rare in Bulgaria, because it is a common practice to harvest honey only two times during the apicultural period (3). Other, but also important factor for the rare production of unifloral honeys in Bulgaria is the great importance of climatic factors which often prevented bees to fly during the blooming period of nectariferous plants.

In spite of the rare production of unifloral honeys, we could agree with other studies that unifloral honeys have an important commercial value because they are regarded as more valuable, often offered for sale at higher prices than the multifloral honeys (31).

From the presented data, we could conclude that from 2000 to the present in Bulgaria more than 11 types of bee honey (Fig.1) were harvested and investigated.

In conclusion it could be underlined that Bulgarian kinds types of bee honey have specific sensorial characteristics, high quality and therapeutic potential that could provoke in the future a great interest among bee honey consumers.

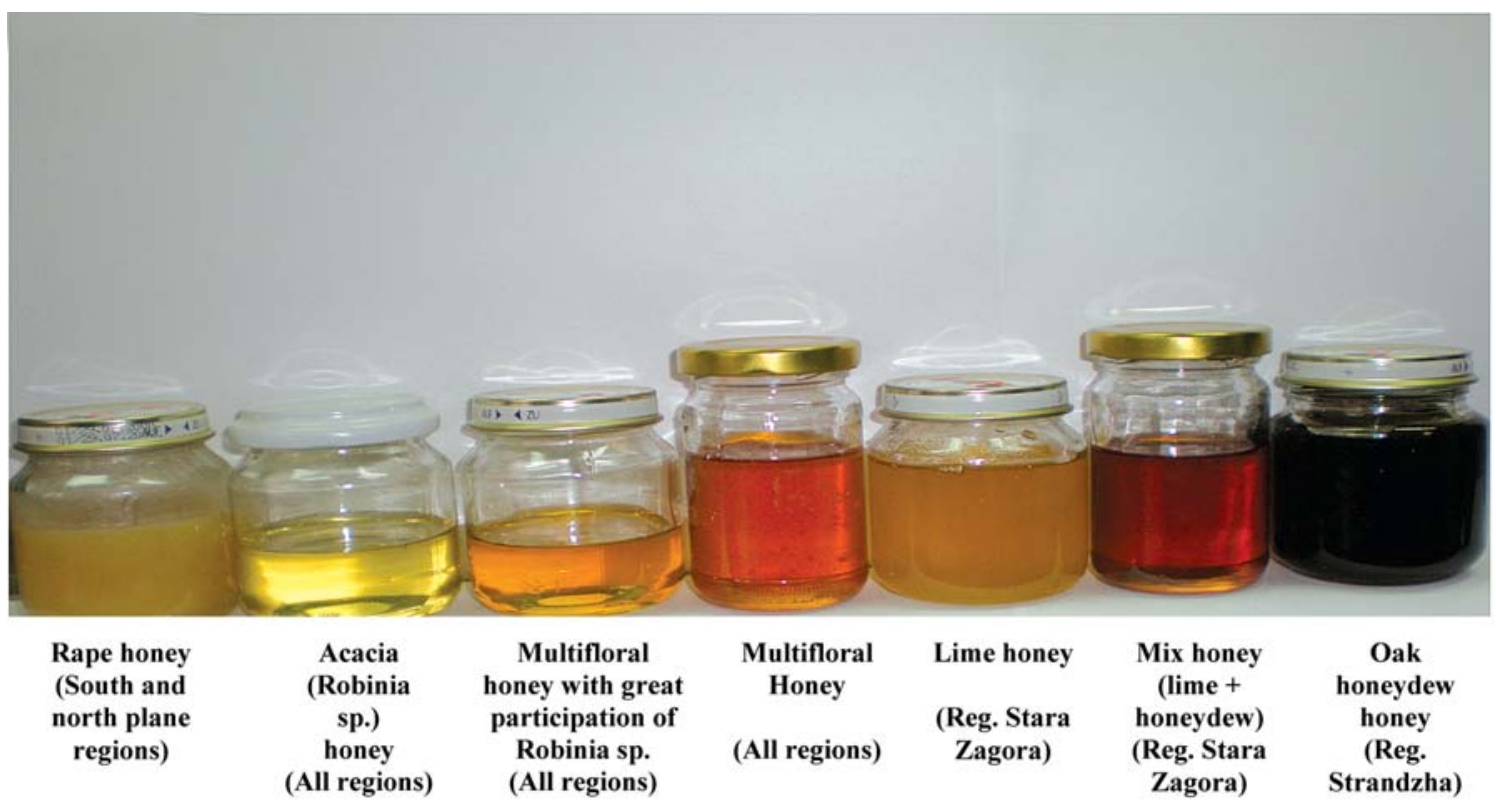

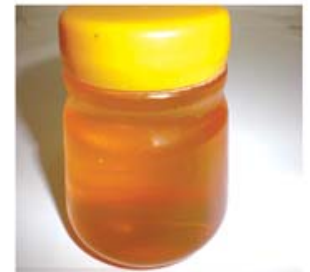

Lavender honey (Reg. Kazanlak)

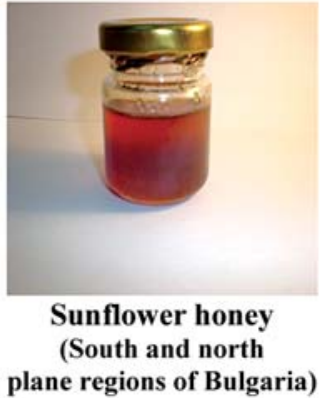

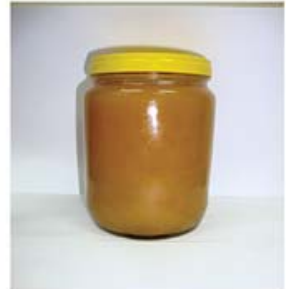

Fennel bee honey (Foeniculum vulgate Mill.) (Reg. Razgrad)

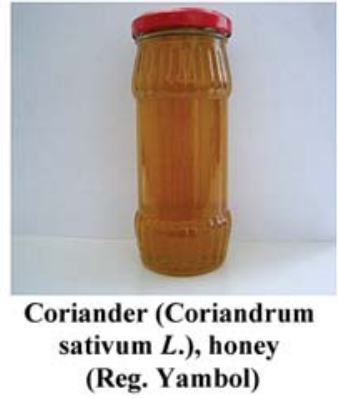

Figure 1. Main kinds of Bulgarian bee honeys from 2000 to present 


\section{REFERENCES}

1. Al-Mamary, M., Ali Al-Meeri, Al-Habori, M. (2002). Antioxidant activities and total phenolics of different types of honey, Nutrition research, 22, 1041-1047.

2. Apostolov, S. Dinkov, D. (2010). Perspectives for Organic Beekeeping in Bulgaria. Program and Abstracts for "First World Conference on Organic Beekeeping", 27 - 29 August 2010, Sunny Beach, Bulgaria, p. 69. http://www.bee-hexagon.net/files/ file/fileE/Organic/ProgramAbstracts.pdf

3. Atanasova, J., Yurukova, L., Lazarova, M. (2012). Pollen and Inorganic Characteristics of Bulgarian Unifloral Honeys. Czech J. Food Sci. 30(6): 520-526.

4. Bankova,V.,Atanassov,At.,Denev, R., Shishinjova,M. (2012). Bulgarian bee products and their health promoting potential. Biotechnol. \& Biotechnol. 26(4): 3086-3088

5. Battaglini, M., Bosi, G. (1973). Caratterizzatione chemico-fisica dei mieli monoflora sulla base dello spettro glucidico e del potere rotatorio specifico. Sci. Technol. Alim., 3, 217-221.

6. Bogdanov, S., Lüllman, C., Martin, P. (1997). Harmonized methods of the European Honey Commission. Apidologie, extra issue, 58-59.

7. Bogdanov, S. (2006). Contaminants of bee products. Apidologie, 37, 1-18.

8. Cwikla, C., Schmidt, K., Matthias, A., K. Bone, M., Lehmann, R., Tiralongo, E. (2010). Investigations into the antibacterial activities of phytotherapeutics against Helicobacter pylori and Campylobacter jejuni. Phytother.Res. 24 (5): 649-656.

9. DIN, (1991). Norm 10754, Bestimmung des Prolingehalts von Honig (Entwurf)

10. Dinkov, D. (2000). A report on the Bulgarian bee honey ripeness according to amount of the aminoacid praline, Acta Entomologica Bulgarica, Suplement 1, 71-74.

11. Dinkov, D. (2003). A scientific note on the specific optical rotation of three honey types from Bulgaria. Apidologie, 34(3): 319-320. INRA/DIB-AGIB/EDP Sciences.

12. Dinkov, D.(2005), Current normative criteria for determination of bee honey quality, Acta Entomologica Bulgarica, Vol. 11, No 3,4, 52-56.

13. Dinkov, D. (2007). Conductivity in Bulgarian multifloral and honeydew honeys. In: Sbornik dokladi ot nauchna konferencia kam LTU "TRADICII I SAVREMENNOST VAV VETERINARNATA MEDICINA", pp. 359-369 (BG).

14. Dinkov, D. (2008). Antioxidant activities of Bulgarian Acacia (Robinia Pseudoacacia L.), Multifloral and Honeydew honeys. Book of abstracts from " $1{ }^{\text {st }}$ World Honeydew Honey Symposium", Apimondia International Honey Commission, 1-3.08.2008 Tzarevo, Bulgaria, p. 38. http://beehexagon.net.
15. Dinkov, D. (2009). Antibacterial activity of bee honey. Pridneprovsky research journal, 10(99): 21-28.

16. Dinkov, D. (2010). Invertase activity from low processing temperatures in different types Bulgarian bee honey. Journal of Mountain Agriculture on the Balkans, Agricultural Academy, Research Institute of Mountain Stockbreeding and Agriculture, 13(1): 71-85.

17. Dinkov, D., Rusev, V. (2000). Physical and chemical studies on bee honey content. National conference with international participation, 1,131-137. Union from Scientists-branch Stara Zagora, 1-2.06.2000 Bulgaria

18. Dinkov D., Vashin, I. (2001). Invertase activity in Bulgarian multifloral and honeydew honeys. Apiacta 36 (2): $57-61$.

19. Dinkov, D., Rusev, V. (2001). A study upon the type of unprocessed bee honey. Bulgarian Journal of Veterinary Medicine, 4, Suppl. 1, 35-38.

20. Dinkov, D., Valkova, E. (2009). Investigations on invertase activity in different type's bee honey from two Bulgarian regions. National conference with international partitipation, 4-5.06.2009, Union from Scientists-branch Stara Zagora, Bulgaria

21. Dinkov, D., Ivanov, T. (2009). Sensorial characteristics and composition of Bulgarian's coriander (Coriandrum sativum L.) honey. Proceedings of the $41^{\text {st }}$ Apimondia congress, 15-20 September 2009, Montpellier, France. Beekeeping Technology and Quality - Posters. http://www. apimondia.org/2009/proceedings.htm

22. Dinkov, D., Ivanov, T. (2010). The main quality parameters of bulgarian's coriander (Coriandrum sativum L.) bee honey. Journal of Mountain Agriculture on the Balkans, Agricultural Academy, Research Institute of Mountain Stockbreeding and Agriculture, 13(1): 86-99.

23. European Commission (2002). Council Directive 2001/110/EC of 20 December 2001 relating to honey. Official Journal of the European Communities L10, $47-52$.

24. Evstatieva, L., Hardalova, R., Stoyanova, K. (2007). Medicinal plants in Bulgaria: diversity, legislation, conservation and trade. Phitologia Balcanica, 13(3): 415-427.

25. Hegazi, A.G., Abd El-Hady, F.K. (2009). Influence of Honey on the Suppression of Human Low Density Lipoprotein (LDL) Peroxidation (in vitro). Evid. Based Complement. Altern. Med., 6(1): 113 - 121.

26. Kirkwood, K.C., Mitchell, T.J., Smith, D. (1960). An examination of the Occurrence of Honeydew in Honey. Part I, Analyst 85.

27. Kirkwood K.C., Mitchell, T.J., Rose, I.C. (1961). An examination of the Occurrence of Honeydew in Honey. Part II, Analyst 86. 
28. Kozhuharov, S., Anchev, M., Petrova, A. (1988). The phanerophytic genefund in Bulgarian flora and its conservation. In: Velkov, D.(ed.), Proc. 10 ${ }^{\text {th }}$ Dendrol. Congr., 03-08.1988, Sofia. pp. 128-137. Bulg. Acad. Publishing House, Sofia

29. Lazarova, M. A., Atanassova, J. R., Yurukova, L. D. (2010). Botanical origin and inorganic content of bee honey in Northeast Bulgaria (Shumen region). Phytologia Balcanica, 1, 131 - 135.

30. Miguel, M. G., Cruz, C., Faleiro, L., Simoes, M. T., Figueiredo, A. C., Barroso, J. G., Pedro, L.G. (2010). Foeniculum vulgare essential oils: chemical composition, antioxidant and antimicrobial activities. Nat.Prod.Commun. 5(2): 319-328.

31. Oddo, L.P., Bogdanov, S. (2004). Determination of honey botanical origin: problems and issues. Apidologie, 35, 2-3.

32. Oddo, L.P., Piazza, M.G., Sabatini, A.G., Accorti, M. (1995). Characterization of unifloral honeys, Apidologie, 26, 453-465.

33. Oddo, L.P., Sabatini, A.G., Accorti, M., Colombo, R., Marcazzan, G.L., Piana, M.L., Piazza, M.G., Pulcini, P. (1997). I mieli uniflorali italiani-Nuove schede di caratterizzatione. Ministero delle Politiche Agricole e Forestali, 30-31.

34. Oddo, L.P., Piana, L., Bogdanov, S., Bentabol, A., Gotsiou, P., Kerkvied, J., Martin, P., Morlot, M., Valbuena, A.O., Ruoff, K., von der Ohe, K. (2004). Botanitical species giving unifloral honey in Europe. Apidologie, 35, 82-93.

35. Pai, M. B., Prashant, G. M., Murlikrishna, K. S., Shivakumar, K. M., Chandu, G. N. (2010). Antifungal efficacy of Punica granatum, Acacia nilotica, Cuminum cyminum and Foeniculum vulgare on Candida albicans: an in vitro study. Indian J.Dent.Res. 21 (3): 334-336

36. Parvanov,P.,Dinkov,D., Tananaki,Chr.,Mihaylova,G. (2011). Sensorial characteristics and composition of Bulgarian's fennel (Foeniculum vulgate Mill.), bee honey: I. Quality parameters. Journal of Mountain Agriculture on the Balkans, Agricultural Academy, Research Institute of Mountain Stockbreeding and Agriculture, 14(1): 1-22.
37. Parvanov, P. Dinkov, D. (2012). More insight into organic bee honey processing, storage and shelf life. Bulgarian Journal of Veterinary Medicine, 15(3): 206-210.

38. Parvanov, P., Dinkov, D., Tananaki, C. (2012). Invertase activity and carbohydrate spectrum of organic acacia and polyfloral honey after one-year storage. Bulgarian Journal of Veterinary Medicine, 15(3): 198-205.

39. Peev, D., Anchev, M., Ivanova, S., Kozhuharov, S., Petrova, S. Tzoneva, A. (1993). Biodiversity of the vascular plants. In: Sakalian, M. (ed.), National Strategy for Biodiversity Conservation. Main reports. Vol. 1, 73-124. The Biodiversity Support Program. Boulvest - 2000, Sofia, Bulgaria

40. Piazza, M.G., Accorti, M., Oddo, L.P. (1991). Electrical conductivity, ash, colour, and specific rotatory power in Italian unifloral honeys. Apicoltura 7, 51-63.

41. Ramos, I. E. L. S., Ferreras, C. G. (2006). Pollen and sensorial characterization of different honeys from El Hierro (Canary Islands). Grana, 45(2): 146-159.

42. Ramos, I. E. L. S., Perez, B. M., Ferreras, C. G. (1999). Pollen characterization of multiforal honeys from La Palma (Canary Islands). Grana 38,356-363. ISSN 0017-3134

43. Ramos, L. S., Perez, B. M., Ferreras, C. G. (2002). Pollen spectra of different unifloral honeys from $\mathrm{La}$ Palma (Canary Islands, Spain). Grana 41 (1): 48-57.

44. Sacchi, R., Bosi, G. (1963).Variabilità nel contenuto di ceneri, ferro, anidride fosforica, calcio, proteine e della rotatione specifica" in mieli italiani. L'Apicoltore d'Italia, 89, 30.

45. Sayed, S.M., El-Ella, G.A.A., Wahba, N.M., El Nisr, N.A., Raddad, K., El Rahman, M.F.A., El Hafeez, M.M.A., Aamer, A.A.E.F. (2009). Immune defense of rats immunized with fennel honey, propolis, and bee venom against induced staphylococcal infection. J.Med.Food 12 (3): 569575.

46. Zhelyazkova, I. (2011). Content of heavy metals and metalloids in bee products produced from the region of Stara Zagora. I.Bee honey. Journal of Agricultural and Forest Science (Sofia), 10, 14-20. 